The Polish Journal of the Arts and Culture. New Series 7

(1/2018): 193-204 [ARTICLE]

DOI: 10.4467/24506249PJ.18.009.9783

\title{
A Friend from a Far Away City
}

\section{A'zam Rahnaward ZARYāB, translation and introduction by Khalil A. ARAB}

\begin{abstract}
About the translator
Khalil A. Arab was born in 1986 in Herat, Afghanistan. He finished his primary and secondary education in Herat. During the Taliban regime, Khalil had to quit school and worked in various jobs to help his family. Following the overthrow of the Taliban, Khalil returned to school in 2002 and finished Herāt Agriculture Vocational High School in 2004. In 2005, he was accepted by the University of Jalālābād, in which he enrolled, only to drop out following a job offer he received from the Americans. Khalil worked as an interpreter/translator for the North Atlantic Treaty Organization (NATO). In June 2010, he fled Afghanistan following a threatening letter he received from the Taliban and eventually settled in Poland as a refugee. In 2011, he enrolled at the Jagiellonian University, where he was awarded a B.A. and M.A. in Persian philology and a B.A. in American Studies. He is currently a M.A. student of American Studies and a PhD student at the Faculty of Philology. His dissertation focuses on Human-Animal Relations in Afghan Contemporary Literature.
\end{abstract}




\section{About the author}

A'zam Rahnaward Zaryāb is one of the most influential and productive Afghan fiction-writers, who had enormous influence on fiction-writing and the younger generation of writers in Afghanistan. Zaryāb was born in 1944, in Rika Khaneh district, Kabul. He was educated at the prestigious Habibiyeh School and received his B.A. in journalism from Kabul University and an M.A. in journalism in the UK. Zaryāb worked as a journalist for Žowandūn weekly as well as the Eslāh newspaper. He was also employed as Art Director at the Ministry of Information and Culture; later, he managed a periodical entitled, Aryana (Republic) Afghanistan Quarterly, which was published in English. He became editor of the newly established The Kabul Times, worked as secretary of the story section of the Afghanistan Writers' Union, and, between 1990 and 1992, was the head of the Afghanistan Writers' Association. After a while, he left for France and lived there for years. Following the American invasion of Afghanistan, he returned to his country in 2003 and briefly worked as senior advisor for the Ministry of Culture.

Zaryāb began writing stories since he was in high school. During his writing career, Zaryāb has written more than 100 short-stories and half-a-dozen novels, most of which have been published in Afghanistan and elsewhere. He has also published a number of literary articles as well as translations of works by other authors. According to Mohammadi, his translations have appeared in various media outlet under his initials (R. Z.). His translations have helped him understand fiction and fiction-writing. Besides his translations, his years of studies and living in the UK have given him an advantage over many writers of his time, an advantage he was to benefit from enormously later on during his writing career. ${ }^{1}$

Zaryāb started his writing career with a short story entitled, Flowerless and Leafless (1963), a story in which he followed the romantic tradition of his predecessors. His first attempt at writing was a promising one for a young and dynamic writer. Zaryāb's short stories can be divided into two categories. Those stories that are written before 1970 and those written after. The stories written before 1970 are realistic in style. The characters are chosen from different layers of Afghan society. ${ }^{2}$ Almost all the plots take place within a house or in a household. These are stories of families with a father who appears (most of the time, but not always) as the head of the household,

${ }^{1}$ Hossain M. Mohammadi, Tärikhe Tahliliye Dāstān Newisiye Afghanistan, Cheshmeh, Tehran 2009, pp. 201-2.

2 Ibidem, pp. 203-11. 
a mother, an older brother and the narrator - a young boy or girl - who is the youngest of all. The majority of stories from this period are written in the first person. The narrator tells the story from a limited first-person point of view, only describing the events they witness. Fathers are not in the story, or, if they are around, they are aggressive, always busy, and they do not care for their family. The older brothers in these stories are always depressed, isolated, and useless tramps. Older brothers never get along with fathers. Mothers have a sublime and majestic place in Zaryāb's stories. Mothers are always kind, compassionate, and sympathetic. They always care for their families. Mothers' faces are the most familiar faces in the memories of the narrators. Wall (1963), Art Teacher (1966), Night Owl (1967), Radio (1970), Chain (1970), Evil Boy (1970) are but a few of the stories written during this period.

1970 was a productive and important year for Rahnaward Zaryāb. One can witness a dramatic shift in Zaryāb's world view published in his works in 1970, as opposed to his works published prior to $1970 .^{3}$ According to Mohammadi, the characters are no longer ordinary folks. They are replaced by lonely, isolated, and frustrated individuals, who live their lives in vain, and converse with their shadows. They live rather in their dreams and imagination. Zaryāb seems to have been hugely influenced by and admiring towards Kafka and the Iranian writer Sādeq Hedāyat (1903-1951). He even dedicated a story (from this period) to Hedāyat. ${ }^{4}$ Notes from a Rooster (1971), The YellowColoured Dog (1971), The Hen Who Died (1971), The Old Man and his Cat (1974), The Pen (1974) are but a few of many stories from this period.

Zaryāb's short stories appeared in several collections, most notably in, A Voice from Amongst Centuries (1983), Man of the Mountain (1984), Friend from a far Away City (1987), and Patterns and Thoughts (1988). A publishing house, nashre Zaryāb, has been established to honour his lifetime achievements in writing.

3 In an essay honoring Wasef Bakhtari (1942-) Zaryāb wrote that, in the 1960s, even though he was not, from the organizational perspective, a member of the People's Democratic Party of Afghanistan, he was supporting the idealogy of Parcham (banner). Parcham was one of the factions of the PDPA. Zaryāb wrote that he personally knew faction's leaders and supported faction's strategies and agendas. Zaryāb recalls that he and Bakhtari, who was a member of Faryāne Democratic Novin - New Democratic Movement, which was a Maoism movement, often argued. At the beginning of 1970 s both underwent a review of their political thinking, and questioned their political world view by placing a colossal question mark in front of them.

4 Ibidem, pp. 211-13. 
We stopped playing for a while, and gazed at the people who were passing in front of us: two men - one of them older, another younger - and three women, with a little boy and a little girl. The little boy was going behind them. He was a chubby little fellow. His head held downward, he had his hands clenched together behind his back. He was wearing a dark-brown PirāhanTombān, shirt, and trousers. ${ }^{1}$ He wore a turban on his head and a pair of black slippers on his feet. He was, perhaps, seven years old. He had a round chubby face and eyes that were coming out of their sockets, as if he was surprised at seeing something. Moving with grandeur and mighty steps, he looked pleasant and ridiculous at the same time.

A couple of steps farther, they entered the Mazāri's ${ }^{2}$ house. This house (which belonged to a family from Mazār-e-Sharif) was known by this name throughout our neighborhood. But since they didn't have a little boy with whom we could play, I didn't know anything else about them.

The next morning, when my father was going to work, and my brother was picking up his handbooks to go to school, I wanted to go out as well. I was hesitant whether to take my toy-car out with me. I promised my Dad that I wouldn't break it. My special little toy-car, that had black rubber tyres and tinted windows, and its shiny bright colour that brought astonishment to every kid's eyes, and my Dad had bought it for me.

I said to myself:

- Perhaps one of those kids hasn't seen my toy-car yet... I will take it out with me today too.

I picked the car from over the shelf and came out to the alley. In the alley, I saw the kids who were sitting on a pile of earth and were busy building sand castles. I walked over to them.

- Let's drive my car - I suggested.

They all came, as if they were all waiting for my suggestion. They destroyed all the sand castles and started to build roads. The roads were built. We named all the cities and the mountain passes along the roads. The car started to roll. I tied one end of a thread to the car and another end to my finger and pulled. We went on several trips to Kandahär and returned to Kabul.

1 Pirāhan-Tombān is the traditional Afghan cloth, consist of a longer shirt that looks like a dress and trousers. Both are worn loose; therefore, they are always tailored to the individual wearing them.

2 Mazāri refers to people who are natives of Mazār-e-Sharif, a city in Balkh province in northern Afghanistan. 
As soon as we were preparing to go on a trip to Mazār-e-Sharif, the Mazāris' door opened, and the same little boy whom I had seen yesterday came out.

He was taking the same haughty steps, with a degree of gravity in every step he took. He stopped for a moment. No one had spoken to him. We were all quite busy travelling towards Mazār-e-Sharif. As we were reaching LatteBand pass, and could see the pass in the near distance, the little boy suddenly started laughing. His laugh was very sincere, and it seemed that he had a very strong reason for his laughter. I looked at him, in silence. He took another step forward. His hands were still clenched together behind his back like yesterday, and his face was glowing from all the blood flowing under its skin. With a specific (Mazāri) accent that I liked it very much, he said:

- Hey! Latte-Band pass is not on the way to Mazär-e-Sharif. The one and only pass on the way to Mazār-e-Sharif, is Shibar.

I asked him embarrassingly:

- Then Latte-Band pass is on the way to which city?

- I don't know on the way to which city it is - he replied - but I am sure it is not on the way to Mazār-e-Sharif. Perhaps it is on the way to Herāt.

My embarrassment was lessened a little, since he also didn't know where Latte-Band pass was.

We changed the names: the pass that was on the way to Mazār-e-Sharif, we called Shibar, and - instead - the pass that was on the way to Herät, we named Latte-Band. A few minutes later, the little boy re-built the road to Mazār-e-Sharif in all its detail. He built Shekāri valley, particularly, with such great detail that we were all astonished. We couldn't even imagine a place with such detail.

When the task of building the road was completed, I asked him:

- What is your name?

He was shy at first, then he replied:

- Rasoul.

- Are you from Mazār-e-Sharif? - I asked.

He replied with his own accent.

- Yes, I am from Mazār-e-Sharif. Our house is near a shrine.

I didn't know what a shrine was. Yet, I shook my head.

- Okay.

I introduced my friends to him and told him my name.

We were playing games until noon that day. Then, we all went home for lunch. I came out of the house in the afternoon. I knew the kids were in 
Chamanak, the little grass-field. A little further from our house was a field whose fences were the walls of the surrounding houses. Inside that field, grass grew; therefore, we called it Chamanak: the little grass-field. In a corner of the field, on a high-point, there was a tomb, above which were raised green, yellow, and red banners. On the tip of the banners, some flat-palm hands made of metal or brass could be seen. At the head of the burial chamber, there were some niches, turned black from the smoke in which people lit and placed candles on Thursday nights. My mother once told me that this tomb is the burial ground of a martyr, and she said they once found a newborn baby on its side, which was adopted by one of the neighbours. Most days, we played football or wrestled on the grass in the field.

That day, when I went to the field of grass, the boys were wrestling. Rasoul wasn't there yet. I sat down and started watching the boys wrestle. Then, he appeared from behind the wall. At first, he paused for a while. Then, he said:

- Hey, here you are. You all came here! I went looking for you near the pile of earth, and couldn't find you. I looked for you in several places, until I found you here. You all are wrestling huh?

- Come and wrestle, can you wrestle? - I asked.

- Yes. In Mazār-e-Sharif we wrestle every day. My brother wrestles too - he answered.

Pāyandeh stood up and invited him to wrestle with him.

- But I don't have my wrestling robe - Rasoul said.

- What do you need a robe for? - I asked him with astonishment.

- Well, how am I supposed to wrestle without a robe? - he replied.

- Without a robe, just like this - I said.

Then, a few people wrestled, in order to demonstrate for him the manner in which we wrestled without a robe. After he observed our wrestling, he then accepted Pāyandeh's challenge. But, in the blink of an eye, I saw both of them spin; Pāyandeh hit to the ground back-first, and Rasoul sat on his chest. I got up and asked him to wrestle with me. Suddenly, I was shaken and then fell down on my back, while Rasoul fell on me with all his weight. Ashamed, I stood up and asked him - How do you do that?

He taught us all the trick. It was very easy. He would lock our right hand under his left arm, then he would hold our right arm with the same hand. After this, he would turn and lock his right leg around our right leg, and would lean forward with all his weight pushing us downwards. Con- 
sequently, we both would fall down; however, we would fall on our backs, and he would fall on us. Although we all learned this trick, none of us could use it properly.

After that, we chatted about everything. He told us a lot about Mazār-eSharif, and then asked:

- How many days are left until the jashn - celebration? ${ }^{3}$

- Four more days - I answered.

- We will return to Mazār-e-Sharif after the celebration - Rasoul said.

- Going back? - I asked.

- Yes. By the way, do they hold a good feast in Kabul? - Rasoul asked.

- Very good. You will see it for yourself then - I replied.

- Where does the celebration take place? - he asked once again.

- In Chamane Hozūri - I answered. - It is not far from here. Do you want to go there? They are installing the lights and raising the flags.

- No. We won't go today. We will go tomorrow. Will the light go on? he asked.

- Not now. They will go on, only during the celebration - I replied.

- What time you will go there tomorrow? - Rasoul asked.

- We can go in the afternoon - I answered.

He was very excited.

- Afternoon - he repeated.

- Yes, we will all go - I assured him.

The next day, we went to Chamane Hozūri together. It was the second half of July, and that year the weather wasn't so nice. I showed Rasoul everything, the lights, the flags, and even the pond upon which the paddle-boats and other watercraft were sailing. Suddenly, a dark cloud hovered over us and covered the sky, and we returned towards home. As we passed Chamane Hozūri behind us, hail began falling. The hailstones were big and heavy. We hid under the birch trees. Everything fell apart and everyone was running in every direction. The hailstones were popping the colourful light bulbs over our heads and around us, and the glass fell and shattered on the ground.

A little while later, a strong wind started to blow. The flags were flying in the air, the wreaths of flowers had collapsed, and the strings of light bulbs were torn apart. The hail came to a halt and people started looting. We took part in the looting and returned home with pockets full of stuff. Then, a few

3 Here Rasoul is referring to the celebration of Afghan Independence Day. 
police vehicles arrived and people escaped. When we arrived at our neighbourhood, every one of us had several red and green light bulbs; only Rasoul returned empty-handed.

- What happened to you that you didn't take anything? - I asked him.

With insincere regret, he answered:

- Well, I said to myself, if they arrest us.

- Who arrested us? They cannot arrest all the people. Other people took more than we did. I say you were scared - I protested.

His lips and nostrils started trembling, his eyes turned watery and he broke into tears. At this point, all the other kids were gone and the two of us were left alone. I asked him:

- Why? Why are you crying? I didn't say anything. Stop crying, people will laugh at you. - But he couldn't stop weeping.

- To tell you the truth, in my heart I didn't want to take the light bulbs. If I could, I would've stopped others from taking them as well. The fact of the matter is what will they light up during the nights of the festival?

I laughed and said:

- They have more light bulbs. They have a lot.

- No, no! It wasn't right. It wasn't right! - he protested.

I was surprised by what he was saying. My friends and I didn't think it wasn't right. In fact, from time to time we would secretly take melons from the stalls $\mathrm{s}^{4}$ in the marketplace. Therefore, I asked him:

- What is wrong with that, we...

But he carried on weeping and standing his ground firmly:

- It's wrong. It's wrong.

His sincere weeping had an enormous impact on me.

- Okay! Okay! What shall we do with these, then? - I asked him.

He stopped crying:

- How many did you take? - he asked.

- Eight. So, what do we do with them, now? - I asked again.

With a great deal of force, he pulled me by the arm and said:

- We will take them back. We take them back.

When we arrived at Chamane Hozüri the sky was clear. No wind was blowing and the sun was about to set. The workers were reconnecting the

4 In Kabul, until recent years, the fruit and vegetable stalls, either located in a local neighbourhood or in a larger market place, were unguarded. The stalls were made of and or fortified with a layer of naturally woven fiber, like straw or tarpaulin. 
string lights. A fat man wearing white glasses was standing near a green car. He seemed irritated and was ordering others around. We approached him with fear and apprehension. He didn't see us at first. We couldn't say a word. We were standing there in silence. As soon as he looked upon us, I showed him the light bulbs:

- Please take these light bulbs.

The irritation disappeared from his face and was replaced with a kind smile. Then he said:

- Where did you find them?

- We took them from other kids - I said.

The fat man called someone, he handed the man the light bulbs, and then said to us:

- Well done children! - Then he called for his driver and asked him to give us a ride and show us around the Chaman. The driver opened the door for us. We jumped into the car. The car started moving, and we felt at a very pleasant peace inside its comfortable seats.

From that day, I grew extremely fond of Rasoul. In my opinion, he was different from others. He was a noble person. He came to our house one day before the celebration. Happiness and joy gleamed in his eyes:

- Tomorrow is the festival, right? - he asked.

- Yes. Tomorrow at this time, there will be a parade - I said.

- What is a parade? - he asked again.

- The military show off their tanks and artillery so that people can see them.

- Will you go to see them tomorrow? - he asked.

- Yes, I'll go. Will you go too? - this time, I asked.

- My uncle said he will take me, but I will go with you. We will go together. What did you do to the toy-car? - he said.

I brought the toy-car and he began to entertain himself by watching it.

- What a beautiful little car - he confessed.

- Do you like it? - I asked.

- Very much. Who bought it for you? - he demanded.

- My father - I said.

He returned the car in the most humble manner possible.

- My father is dead - he sighed. 
I looked at him. He had the most piteous look on his face. I empathized with him.

- When did he die? - I asked him.

- Two years ago. He was coughing. He died from coughing - he replied. We didn't talk anymore and went on playing. This time, he was the driver. $* * *$

Finally, the day of celebration had arrived, and, early in the morning, we went to Chaman. By the time we arrived, there was a big crowd of people; the crowd was so big, adding to our short height, that we wouldn't see the parade. We looked around for hours, trying from every angle and every corner to no avail. By this time, the parade had already started, and we could only hear the band playing and see the tanks' main gun barrels. That was it. Then tired and disappointed, we returned home.

The same afternoon - excited and joyful - we went to Chaman. We both had twelve Afghanis ${ }^{5}$, and I asked Rasoul:

- Let's go to Carnival, what do you think?

- What is a carnival? - he demanded.

- Let's go, you will see. It's entertaining - I assured him.

The funfair was fortified with straw-mat fences. The entrance ticket for the funfair would cost one Qarān. ${ }^{6}$ Plenty of games of chance and skill were to be seen in every corner. Various different sounds were mixed up together, while the advertising voices, whose task was calling to attract spectators, were the loudest. A man called:

- The lucky ones, will come on this way.

Another called:

- Bet big, win big.

While another man called:

- Win up to four times your money's worth.

Rasoul was mesmerized. I pulled him by his arm and walked him to the shell game stand. We played, and we won five Afghanis. Rasoul had lost it completely. I played once again, and I won again. But I lost the third time. At some point our money reached eighty Afghanis. We were in pure ecstasy

5 Afghani is the term used for Afghanistan's currency. It is hard to establish the value of that (twelve Afghanis) since the story has been written in 1964.

${ }^{6}$ Qarān was the smallest existing coin in Afghanistan at this time, and its value was half of an Afghani. Pül (literally means money, and equivalent of a penny), on the other hand, was the smallest coin in the past. However, this coin didn't exist anymore at the time the story was written. 
and completely unfocused. Then, when we came to our senses once again, we didn't have a penny in our pockets. We had lost all our money. We came out of the funfair angry and depressed. We didn't wish to talk to one another. We felt that we had lost something precious. We were pretty choked up; it was an obscure urge for cry. It was already dark. We didn't pay attention to the colourful lights around us. We were walking home defeated. That night, my father showered me with curses, and my brother slapped me in the face very hard. I broke into tears and wept.

We (Rasoul and I) spent the days of carnival together. We grew fond of one another. When we weren't spending time together, a kind of sorrow would overtake me. The festival was over, and we witnessed how they removed the lights and the flags. One day Rasoul asked:

- Why are they removing them? They should allow the celebration to continue. People go to work during the day, and during the night take their children to the celebration.

I sank into thought. I couldn't find any reason for that. I asked myself:

- Actually why won't they allow every day to be a celebration?

Two more days passed. In those two days, Rasoul seemed very troubled. I asked him several times:

- What is bothering you?

But he wouldn't say anything. Only once he sighed:

- Listen!

- Listen to what? - I asked.

- I wish we had a flying carpet - he told me.

- You mean Solomon's carpet? The one that flies? - I enquired.

- Yes. If we had one, in a span of one hour, it would take us to Mazār-eSharif and bring us back.

The next morning, I was still sleeping when my mother woke me up.

- Rasoul is here. He wants to see you - my mother announced.

I went through the front yard to the main gate. I saw Rasoul like the first day I saw him. He was standing out in the alley. He was wearing the same pair of black slippers, the same Pirāhan-Tombān, and his hands were clenched together behind his back in the same manner. He seemed overwhelmed. His lips were trembling, and he was choked up.

- I am leaving today - he announced.

I was shocked. 
- Are you serious? - I asked him.

- Yes. We are leaving now. I came to say good bye to you - he said.

I wanted to weep. He didn't look any better. While he was trying to avoid eye contact with me and playing with the iron door knocker, he said:

- Look! If you ever came to Mazār-e-Sharif make sure you come to our home. Our house is in Siyāhgard Street. Anyone you ask there will show you where the street is... We have an orchard. If you ever come, I will take you there to see it. It is not very big, but it has plenty of fig, almond and pomegranate trees. There is a water stream as well. Make sure you come. Okay!

At this point, the Mazāri's door opened and two men, one old, another young, three women, with a little girl, came out. They stood at the threshold for a moment and exchanged a few words with those standing on the other side of the threshold. They called Rasoul and then walked towards the main street. Rasoul pressed my hands in his fingers indecisively and asked:

- Will you come? Yes, promise?

- Yes. Yes, if I ever came to Mazār-e-Sharif, I will look for your house... in Siyāhgard Street... - I promised him.

He held his head down and left. I called after him:

- Wait! Wait a minute! - I ran to the house quickly. I went into my room and took my toy-car from the shelf. I looked at it for a moment. I couldn't see through it, and its colours had a sort of attractiveness. I ran back out and gave it to Rasoul. - Keep it.

His face lightened up. He tucked the car under his arm and followed the little girl. He didn't have that mighty grand look anymore. He walked restlessly, and, until they disappeared at the turn of the street, he kept turning around and looking at me... 